\title{
PENINGKATAN LAYANAN PERPUSTAKAAN DENGAN MEDIA SMS GATEWAY: STUDI KASUS PERPUSTAKAAN KEBUN RAYA BOGOR
}

\author{
Oleh: \\ Sutarsyah \\ Pusat Perpustakaan dan Penyebaran Teknologi Pertanian \\ Jalan Ir. H. Juanda no. 20 Bogor \\ e-mail: sutarsyah2@yahoo.com
}

\begin{abstract}
ABSTRAK
Pemanfaatan teknologi informasi dan komunikasi perlu dilakukan untuk meningkatkan layanan perpustakaan ke pemustaka, dalam tulisan ini Perpustakaan Kebun Raya Bogor melakukan layanan SMS sebagai media komunikasi untuk meningkatkan layanan perpustakaan. Layanan SMS dilakukan karena ruang perpustakaan pindah dan memiliki jarak yang cukup jauh sekitar $2 \mathrm{~km}$ dengan kantor utama, sebagai pusat segala aktifitas termasuk peneliti sebagai pengguna aktif perpustakaan. Hal ini menyebabkan akses ke perpustakaan jauh sehingga berdampak pada jumlah kunjungan para peneliti menurun, terlambat dalam penyampaian informasi-informasi baru, dan tingkat disiplin pengembalian buku ke perpustakaan menjadi kurang baik. Tujuan dari layanan ini untuk mengetahui respon peneliti terhadap layanan SMS Gateway. Metode penelitian dilakukan dengan melakukan uji coba prototip SMS Gateway. Hasil penelitian selama kurang lebih satu bulan menunjukkan respon positif dari 7 orang peneliti dengan permintaan beberapa artikel yang dibutuhkan untuk dicarikan literaturnya oleh perpustakaan.

Kata kunci: Teknologi informasi, SMS Gateway, Perpustakaan Kebun Raya Bogor-LIPI
\end{abstract}

\section{ABSTRACT}

Utilization of information and communication technology needs to be done to improve library services to the library, in this writing Bogor Botanical Garden Library performs SMS services as a communication medium to improve library services. SMS service is done because the library room is moved and has a considerable distance of about $2 \mathrm{~km}$ with the main office, as the centre of all activities including researchers as active users of the library. This led to access to distant libraries resulting in the number of visits of researchers declining, being late in the delivery of new information, and the level of discipline of returning books to the library to be less good. The purpose of this service is to find out the researcher's response to the SMS Gateway service. The research method is carried out by conducting a prototype trial of SMS Gateway. The results of the study for approximately one month showed a positive response from 7 researchers with the request of several articles needed to find literature by the library.

Keywords: Information technology, SMS Gateway, Bogor-LIPI Botanical Garden Library

\section{Pendahuluan}

Perkembangan Teknologi dan Informasi memberikan peran strategis bagi perpustakaan sebagai pengelola informasi untuk memaksimalkan layanan informasi kepada penggunanya. Hal ini dikarenakan ilmu pengetahuan dan teknologi membutuhkan informasi sekaligus menghasilkan informasi sebagai konsekuensi logis dari perkembangan dibidang ilmu pengetahuan dan teknologi dewasa ini (Ansor, 2016). Sebagai lembaga informasi, perpustakaan dituntut untuk lebih kreatif dan proaktif dalam menyampaikan informasi dan menciptakan konten yang berkualitas.

Oleh karena itu dalam rangka meningkatkan layanan informasi kepada pengguna, Perpustakaan Kebun Raya Bogor (KRB) - LIPI memberikan layanan berbasis SMS (Short Messages Services), dengan melakukan uji coba protipe SMS Gateway, berupa pesan langsung atau instant messaging. SMS merupakan sebuah teknologi yang menyediakan pelayanan pengiriman dan penerimaan pesan antar mobile phone. SMS menjadi media yang digunakan pada layanan perpustakaan karena, komunikasi melalui SMS dapat dilakukan oleh semua jenis telepon genggam, baik smartphone maupun non smartphone (Bielskas dan Dreyer, 2012), dan teknologi dalam penyelenggaraan SMS termasuk sederhana dan murah (Stahr, 2009). 
Alasan lainnya SMS dijadikan sebagai media komunikasi karena di Indonesia jaringan internet belum merata sehingga penggunaan SMS dalam layanan perpustakaan berpotensi menjangkau seluruh pengguna telepon genggam, baik penguna smartphone maupun non smartphone (Wicaksono, 2017). Hal ini diperkuat dengan data dari Kementerian Komunikasi dan Informatika dalam rencana strategisnya tahun 2015-2019 menyatakan bahwa kesenjangan digital di wilayah Indonesia masih tinggi.

Latar belakang layanan SMS di Perpustakaan KRB, karena Sejak bulan Agustus 2010, ruang perpustakaan pindah dan memiliki jarak yang cukup jauh dengan kantor utama, yakni sekitar $2 \mathrm{~km}$. Kantor utama menjadi pusat segala aktifitas, mulai dari kegiatan administrasi, ruang pimpinan, dan ruang kerja para peneliti, dimana peneliti selama ini sebagai pengguna aktif perpustakaan. Hal ini menyebabkan akses ke perpustakaan menjadi jauh dan berdampak pada jumlah kunjungan para peneliti sebagai pengguna aktif perpustakaan menurun, keterlambatan dalam penyampaian informasi-informasi baru, dan tingkat disiplin pengembalian buku ke perpustakaan menjadi kurang baik.

Oleh karena itu pada penelitian ini penulis melakukan uji coba prototipe SMS Gateway sebagai media mendekatkan, memudahkan dan mempercepat layanan perpustakaan tanpa terhalang jarak, dalam rangka meningkatkan layanan Perpustakaan KRB untuk pemenuhan kebutuhan referensi peneliti di KRB dan sebagai media pengingat kepada pemustaka mengenai batas waktu peminjaman buku dan pengoptimalan penggunaan bukubuku yang ada di perpustakaan.

\section{Tujuan Penelitian}

1. Untuk mengetahui respon peneliti terhadap layanan SMS Gateway

2. Untuk mengetahui jumlah publikasi dari masing-masing peneliti

3. Untuk mengetahui topik yang menjadi penelitian dari masingmasing peneliti

\section{Metode Penelitian}

Metode Prototip merupakan metodologi pengembangan software yang menitikberatkan pada pendekatan aspek desain, fungsi dan user-interface. Developer dan user fokus pada user-interface dan bersama-sama mendefinisikan spesifikasi, fungsi, desain dan bagaimana software bekerja. Developer dan user bertemu dan melakukan komunikasi dan menentukan tujuan umum, kebutuhan yang diketahui dan gambaran bagian-bagian yang akan dibutuhkan. Developer mengumpulkan detail dari kebutuhan dan memberikan suatu gambaran dengan cetak biru (prototip). Dari proses tersebut akan diketahui detail-detail yang harus dikembangkan atau ditambahkan oleh developer terhadap cetak biru, atau menghapus detail-detail yang tidak diperlukan oleh user. Proses akan terjadi terus menerus sehingga produk sesuai dengan keinginan dari user. (Yazdi, 2012)

Prototipe merupakan model atau hasil perancangan sederhana yang belum lengkap dan dibuat sebagai alat untuk eksplorasi, evaluasi dan komunikasi. Prototipe membantu memvisualisasikan hasil desain dan memberikan gambaran bagaimana suatu perangkat lunak bekerja (Galitz, 2007) Kajian dilakukan pada tanggal 1 November 2016 sampai dengan 31 Desember 2016. Untuk memudahkan penelitian, penulis mengidentifikasi publikasi peneliti dan media pencarian informasinya. Hal ini dilakukan untuk mengetahui topik tulisan dari masingmasing peneliti untuk memudahkan pemberian informasi yang tepat sesuai kebutuhan

\section{Pembahasan}

\section{Identifikasi Publikasi Peneliti}

Pada tahap awal, penulis mengidentifikasi jabatan fungsional pada Kelompok Peneliti (Kelti) di Kebun Raya Bogor (KRB)-LIPI. Dari hasil identifikasi diketahui jumlah peneliti dari masing-masing Kelti, mengetahui namanama penelitinya, subyek penelitian, publikasi yang sudah dihasilkan. Jumlah peneliti KRB sebanyak 52 orang, yang 
terbagi kedalam empat kelompok penelitian. Pengelompokan jabatan fungsional penelitian di Kebun Raya Bogor dimaksudkan untuk meningkatkan jumlah dan mutu penelitian konservasi dan pendayagunaan tumbuhan di Kebun Raya Bogor serta menjadikan bidang keahlian staf peneliti menjadi lebih fokus untuk melaksanakan kegiatan penelitiannya.
Adapun ketiga kelompok tersebut adalah sebagai berikut: (1) Kelti Botani Ekonomi, (2) Kelti Domestikasi, (3) Kelti Konservasi Tumbuhan, (4) Kelti Reintroduksi, Restorasi dan Perubahan Iklim.

Berikut tabel publikasi para peneliti

Tabel 1 Draft Tabel Peneliti Kebun Raya Bogor

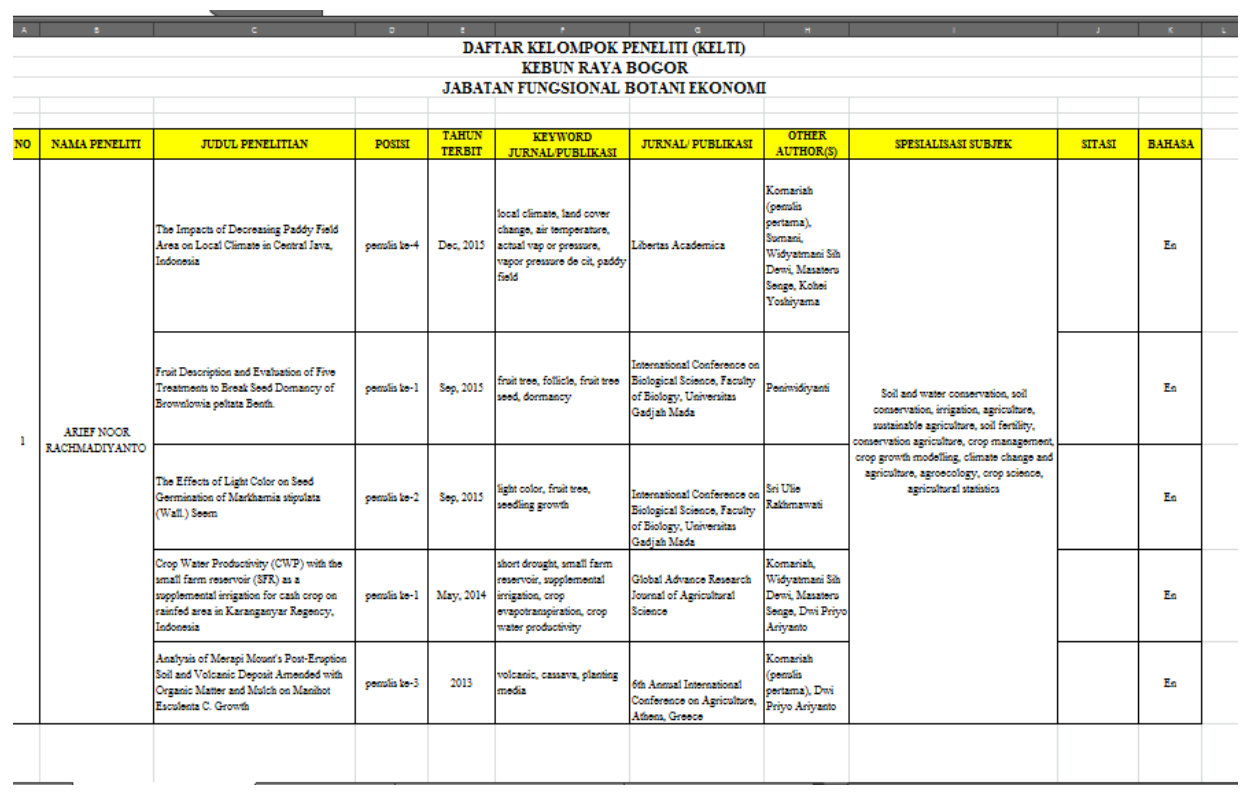

Analisis Publikasi dan Topik Peneliti a. Jabatan Fungsional Botani Ekonomi

Fungsi botani ekonomi merupakan ilmu yang mempelajari kegunaan tumbuhan bagi manusia dan memiliki nilai ekonomis. Disiplin ilmu ekonomi botani merujuk secara khusus pada kajian nilai ekonomi pada suatu Berikut publikasi peneliti kelti botani ekonomi tumbuhan, yaitu dengan menekankan pada usaha-usaha penemuan tumbuhan yang dapat mendatangkan kepentingan secara global atau bermanfaat bagi pembangunan negara dan masyarakat. Pada fungsi botani ekonomi terdapat enam peneliti, yaitu:

Tabel 2 Publikasi Peneliti Kelti Botani Ekonomi

\begin{tabular}{|c|l|l|l|}
\hline \multirow{2}{*}{ Tahun } & \multicolumn{1}{|c|}{ Jumlah Artikel } \\
\cline { 2 - 4 } & \multicolumn{1}{|c|}{ Subjek } & $\begin{array}{c}\text { Bahasa } \\
\text { Indonesia }\end{array}$ & \multicolumn{1}{|c|}{$\begin{array}{c}\text { Bahasa } \\
\text { Inggris }\end{array}$} \\
\hline 2013 & soil and water conservation & 0 & 5 \\
\hline 2010 & $\begin{array}{l}\text { plant pathology, plant protection, phytopathology, integrated pest } \\
\text { management, crop protection, disease diagnosis, plant bacterial } \\
\text { diseases, }\end{array}$ & 13 & 1 \\
\hline 2010 & Economic botany, aquatic plant, phyteromediation & 5 & - \\
\hline 2014 & Economic botany, Zingiberaceae & 5 & - \\
\hline 1997 & $\begin{array}{l}\text { Medicinal plant conservation, biodiversitas, ecology, ethnobotany, } \\
\text { economy botany. }\end{array}$ & 57 & 12 \\
\hline 2007 & Botany, plant breeding and biotechnology, domestication. & 12 & 4 \\
\hline \multicolumn{1}{|c|}{ Jumlah } & 92 & 22 \\
\hline
\end{tabular}




\section{b. Jabatan Fungsional Domestikasi}

Fungsi domestikasi merupakan program yang meliputi kajian studi berbagai aspek domestikasi yang diawali dari karakterisasi, seleksi, hingga pemuliaannya. Kelompok Peneliti Domestikasi Kebun Raya Bogor memfokuskan diri untuk melakukan penyeleksian komoditas produk pangan dan tanaman hias. Adapun jenis-jenis yang ditangani adalah tanaman buah, umbi-umbian, dan tanaman hias. Pada fungsi domestikasi terdapat tiga belas peneliti, yaitu:

Tabel 3 Publikasi Peneliti Kelti Domestikasi

\begin{tabular}{|c|c|c|c|}
\hline \multirow[b]{2}{*}{ Tahun } & \multicolumn{3}{|l|}{ Jumlah Artikel } \\
\hline & subjek & $\begin{array}{l}\text { Bahasa } \\
\text { Indonesia }\end{array}$ & $\begin{array}{l}\text { Bahasa } \\
\text { Inggris }\end{array}$ \\
\hline 2009 & plants, conservation, tissue culture, horticulture, biotechnology & 14 & 5 \\
\hline 2013 & palm, ornamental plant, medicinal plant, local fruit, ethnobotany & 7 & 0 \\
\hline 1991 & begonia, plant propagation, seedlings growth, & 32 & 5 \\
\hline 1987 & $\begin{array}{l}\text { ecosystem, plant vegetation, diversity, vegetation, lowland } \\
\text { freshwater swamp vegetation, lowland peat swamp vegetation, }\end{array}$ & 48 & 13 \\
\hline 2009 & plant biotechnology, cel culture, culture in vitro, plant organt. & 1 & 1 \\
\hline 2011 & orchird, plant tissue culture, conservation biology. & 2 & 0 \\
\hline 1990 & $\begin{array}{l}\text { horticulture, plant biodiversity, fruit plants, plant conservation, } \\
\text { biotechnology. }\end{array}$ & 18 & 18 \\
\hline 2013 & $\begin{array}{l}\text { horticulture, agronomy, agricultural plant science, plant breeding, } \\
\text { plant biotechnology, plant tissue culture }\end{array}$ & 11 & 1 \\
\hline 2009 & food technology, orchidology. & - & 4 \\
\hline 2008 & fruit plants, plant pollination, plant genetic, plant seedlings. & 14 & 2 \\
\hline 1997 & flora, seed germination, plant cultivation, & 9 & 2 \\
\hline 2008 & $\begin{array}{l}\text { seed conservation, climate change, pollination biology, endangered } \\
\text { species, ecology and evolution, biodiversity, conservation biology, }\end{array}$ & 3 & 3 \\
\hline 1998 & $\begin{array}{l}\text { botany, plant tissue culture, pitcher plant, Cibotium barometz, } \\
\text { agarwood, biodiversity, conservation, plant physiology, plant } \\
\text { biotechnology. }\end{array}$ & 22 & 4 \\
\hline & Jumlah & 181 & 58 \\
\hline
\end{tabular}

\section{c. Jabatan Fungsional Konservasi} Tumbuhan

Fungsi konservasi tumbuhan merupakan fungsi penelitian yang memfokuskan pada pengembangan koleksi dan penelitian di bidang konservasi tumbuhan, khususnya tanaman yang masuk pada kategori langka atau terancam punah.

Tabel 4 Publikasi Peneliti Kelti Konservasi Tumbuhan

\begin{tabular}{|c|c|c|c|}
\hline \multirow[b]{2}{*}{ Tahun } & \multicolumn{3}{|l|}{ Jumlah Artikel } \\
\hline & subjek & $\begin{array}{l}\text { Bahasa } \\
\text { Indonesia }\end{array}$ & $\begin{array}{l}\text { Bahasa } \\
\text { Inggris }\end{array}$ \\
\hline 2004 & $\begin{array}{l}\text { seed evolutionary ecology, covering reproductive allocation/effort, } \\
\text { seed mass, maternal effects, seed heteromophism, plant ecology }\end{array}$ & 6 & 6 \\
\hline 2003 & $\begin{array}{l}\text { botany, seeds, plant conservation, Amorpophallus titanum, } \\
\text { Rafflesia. }\end{array}$ & 3 & 9 \\
\hline 1997 & $\begin{array}{l}\text { Botany, Medicinal Plants and Herbs, Plant Breeding, Plan Genetics, } \\
\text { Plant Population. }\end{array}$ & 10 & 11 \\
\hline 1987 & conservation, orchirds, plant exploration, seeds, plant tissue & 19 & 3 \\
\hline 1994 & botany, zoology, ecology, conservation & 36 & 8 \\
\hline 2006 & amorphopallus titanum, seeds germination, nepenthes, orchids. & 19 & 1 \\
\hline 1991 & $\begin{array}{l}\text { Oxalidaceae, Bambu, Anacardiaceae, Taxonomy, Fenology, } \\
\text { Conservation, Botany. }\end{array}$ & 26 & 17 \\
\hline 2012 & $\begin{array}{l}\text { plant taxonomy, conservation biology, Botanical Garden, } \\
\text { Sapindaceae, Ebenaceae, pollen germination, molecular systematic }\end{array}$ & 2 & 2 \\
\hline
\end{tabular}




\begin{tabular}{|c|l|c|c|}
\hline 2000 & Taxonomic, phylogeny & 5 & 7 \\
\hline 1998 & $\begin{array}{l}\text { botany, evolutionary biology, molecular biology, systematics } \\
\text { (taxonomy), ecology, bioinformatics, cell biology, biotechnology, } \\
\text { cancer research, microbiology. }\end{array}$ & 26 & 16 \\
\hline 2007 & plant taxonomy, Urticaceae, plant ecology, ethnobotany. & 5 & 6 \\
\hline 1999 & biology, botany & 11 & 1 \\
\hline 1994 & $\begin{array}{l}\text { plant systematics, plant conservation biology, cytotaxonomy, } \\
\text { Pteridology. }\end{array}$ & 13 & 34 \\
\hline 2010 & roses, compost tea, biology, conservation biology, taxonomy. & 1 & 2 \\
\hline 2000 & botany, Rubiaceae, seed germination, vegetative propagation. & 40 & 7 \\
\hline 2010 & botany, Moraceae. & 3 & - \\
\hline 1999 & botany, flora, fern, plant. & 6 & - \\
\hline 2011 & $\begin{array}{l}\text { Hoya (Asclepiadoideae), Conservation Genetics, DNA Barcoding, } \\
\text { Biodiversity, Plant Genetics, plant ecology. }\end{array}$ & 13 & 10 \\
\hline 2010 & botani, Musaceae, Arecaceae & 251 & 142 \\
\hline & \multicolumn{1}{c}{ Jumlah } & 2 \\
\hline
\end{tabular}

\section{d. Jabatan Fungsional Reintroduksi, Restorasi, dan Perubahan Iklim}

Fungsi Reintroduksi, Restorasi, dan Perubahan Iklim merupakan fungsi penelitian yang berfungsi untuk mengenalkan kembali tanaman langka/hampir punah, pemulihan kembali keberadaan tanaman ke keadaan semula, dan mengamati perubahan iklim serta dampaknya terhadap lingkungan, terutama terhadap perkembangan tanaman.

Tabel 5 Publikasi Peneliti Kelti Reintroduksi, Restorasi, dan Perubahan Iklim

\begin{tabular}{|c|c|c|c|}
\hline \multirow[b]{2}{*}{ Tahun } & \multicolumn{3}{|l|}{ Jumlah Artikel } \\
\hline & subjek & $\begin{array}{l}\text { Bahasa } \\
\text { Indonesia }\end{array}$ & $\begin{array}{l}\text { Bahasa } \\
\text { Inggris }\end{array}$ \\
\hline 2015 & plant molecular, genetic conservation & 2 & - \\
\hline 2009 & ecology, biology conservation, climate change. & 12 & 1 \\
\hline 2011 & ecology, evolution. & 6 & 0 \\
\hline 2004 & landscape ecology, spatial analysis, regional science. & 11 & 12 \\
\hline 2005 & reintroduction, seed germination, medicinal plant. & 15 & 3 \\
\hline 2011 & plant ecology, conservation & 2 & 7 \\
\hline 2003 & plant conservation, ethnobotany, phenology, cultivation. & 9 & 2 \\
\hline & biodiversity, conservation, botany, ecology. & 2 & 1 \\
\hline 2013 & ecology, plant conservation. & 3 & - \\
\hline 2001 & Botany, Phylogenetics, Biogeography & 10 & 3 \\
\hline 2015 & seed germination, restoration. & & 1 \\
\hline 1997 & $\begin{array}{l}\text { botany, plant evolution, genetic molecular, Lamiaceae (mint family), } \\
\text { Taxonomy, Palynology (Pollen). }\end{array}$ & 13 & 12 \\
\hline 2007 & $\begin{array}{l}\text { biodiversity, forest ecology, conservation biology, plant conservation, } \\
\text { restoration ecology, conservation, ecological restoration, community } \\
\text { ecology, forest conservation, species diversity, }\end{array}$ & 7 & 16 \\
\hline Jumlah & & 92 & 57 \\
\hline
\end{tabular}

\section{Penyebaran Informasi Seputar Layanan SMS Gateway}

Pada tahap ini, uji coba penyebaran informasi mengenai layanan SMS Gateway kepada para peneliti di Kebun Raya Bogor.

Berikut adalah tahap penyebaran informasi melalui aplikasi SMS Gateway: a. Klik toolbar explore pada bagian bawah windows. Lalu, pada bagian Computer, klik kanan dan pilih manage.

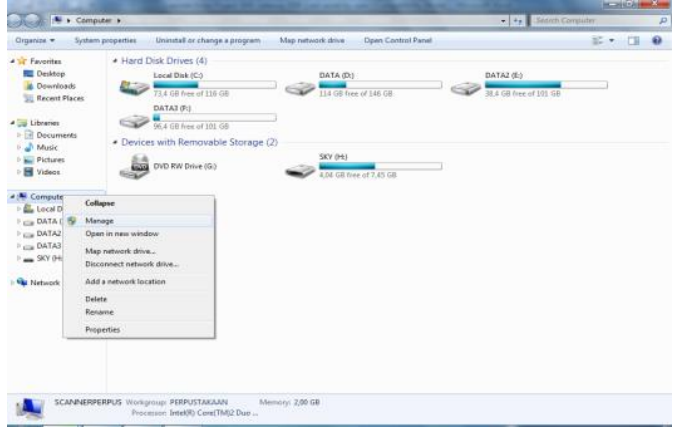

Gambar 1 Penampang explore pada windows 
b. Setelah itu, klik dua kali menu services and applications. Lalu, klik services.

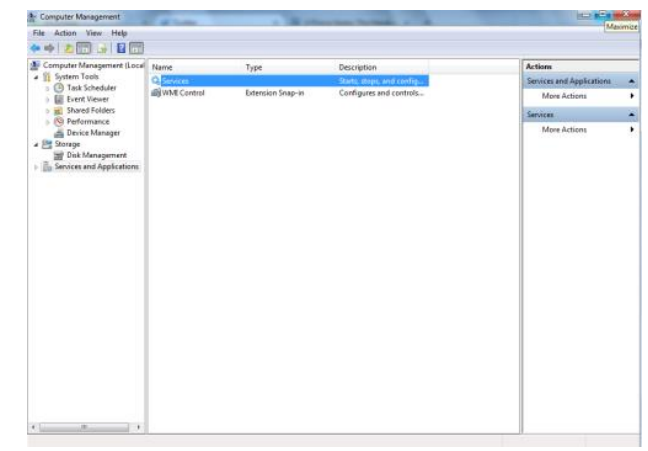

Gambar 2 Penampang computer management

c. Search Gammu SMSD Service (GammuSMSD) dengan menggunakan tombol $\mathbf{C t r l}+\mathbf{F}$ lalu klik start service

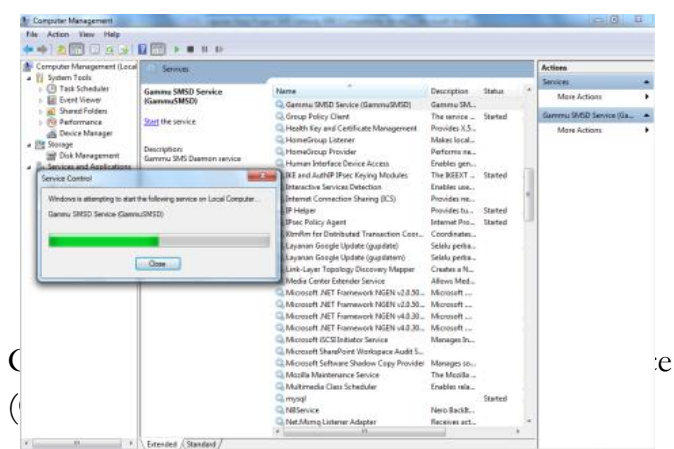

d. Buka browser dan ketik localhost/ krblib_sms. Lalu, login ke dalam sistem dengan menggunakan username dan password.

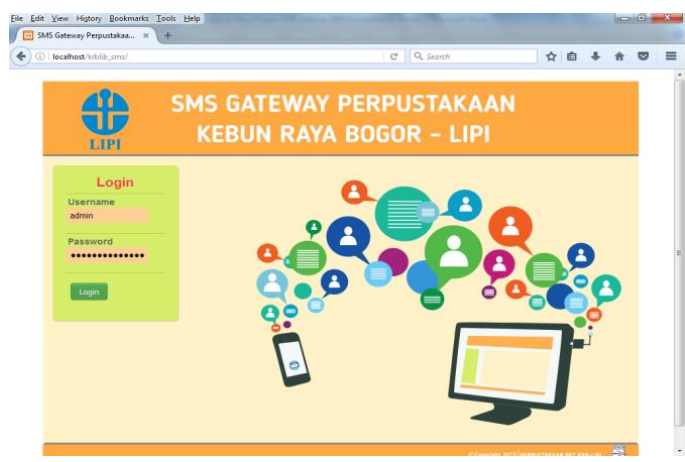

Gambar 4 Halaman depan sistem SMS Gateway

e. Ketikkan pesan pada kotak isi pesan dan kirimkan kepada peneliti di Kebun Raya Bogor.
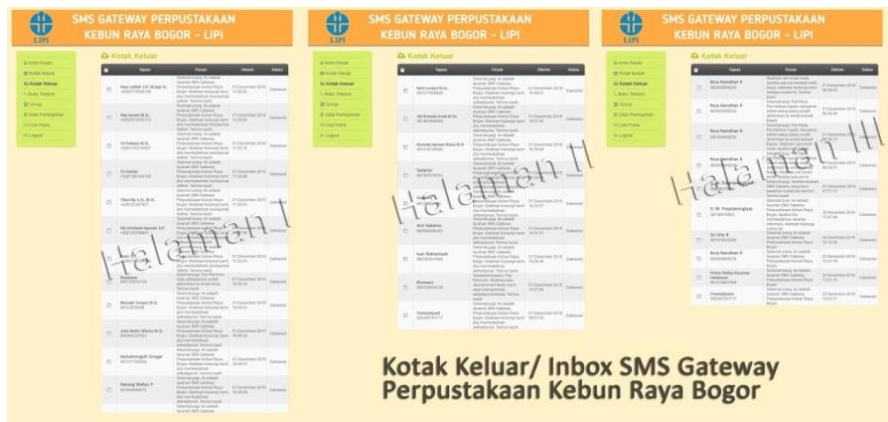

Kotak Keluar/ Inbox SMS Gateway Perpustakaan Kebun Raya Bogor

Gambar 5. Penampang kirim pesan dan kotak keluar 


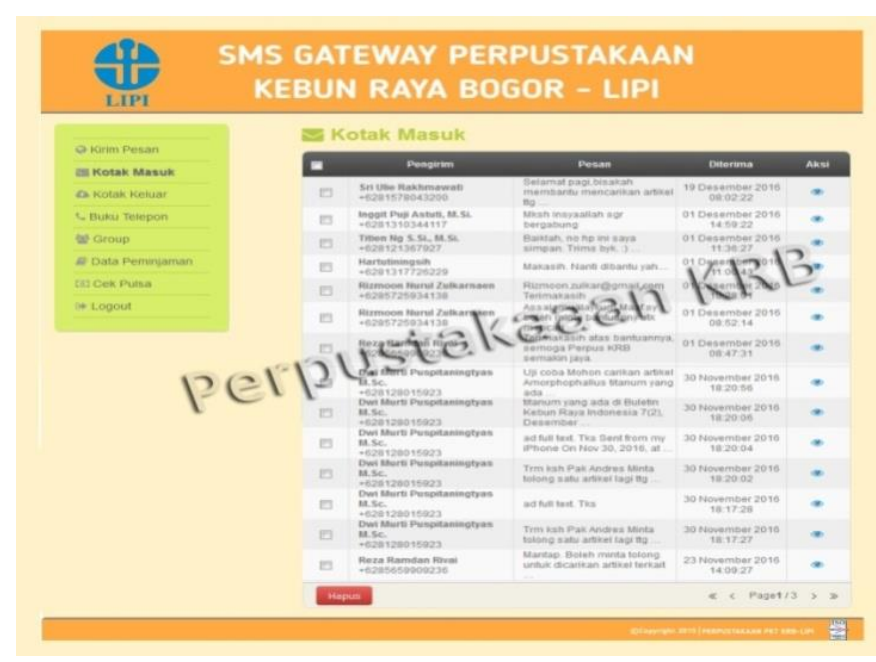

Gambar 6 Respon Positif Peneliti Kebun Raya Bogor

\section{Pencarian Informasi}

Tahap ini merupakan tahap lanjutan dari proses penyebaran informasi seputar layanan SMS Gateway. Peneliti yang membutuhkan informasi mengenai buku/jurnal akan langsung menghubungi pustakawan melalui nomor SMS Gateway yang telah diberikan sebelumnya. Pada uji coba

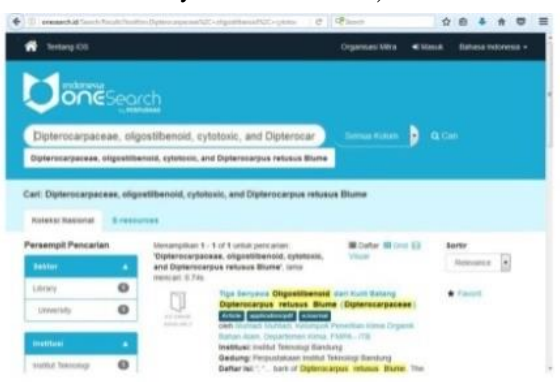

Gambar 8 Contoh Pencarian Melalui Situs Jurnal Nasional
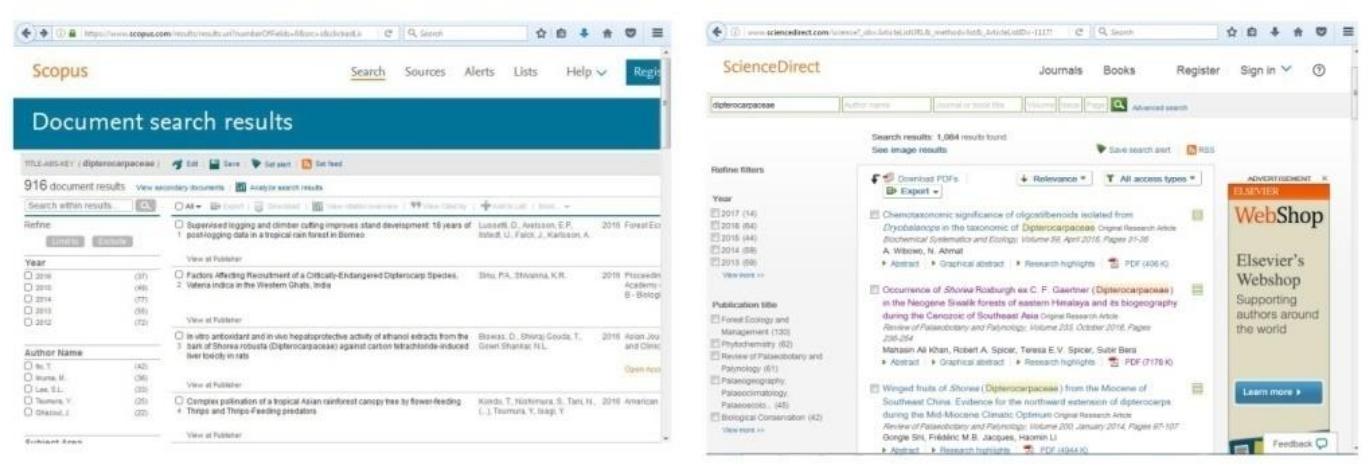

Gambar 9 Contoh Pencarian Melalui Situs Jurnal Internasional

1. Temu-kembali Informasi

Di tahap akhir ini, mengirimkan informasi kepada peneliti di Kebun selama 1 bulan ini ada 7 orang peneliti yang minta dicarikan literaturnya. Situs yang digunakan untuk melakukan pencarian informasi, yaitu beberapa situs jurnal nasional : situs web Perpustakaan Kebun Raya Bogor, (DOAJ dan onesearch.id) dan internasional (Science Direct, Scopus, dan sebagainya)

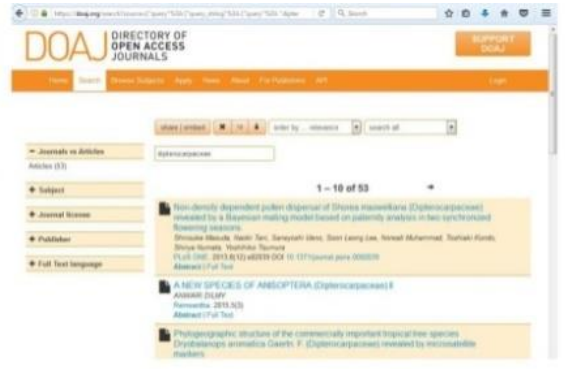




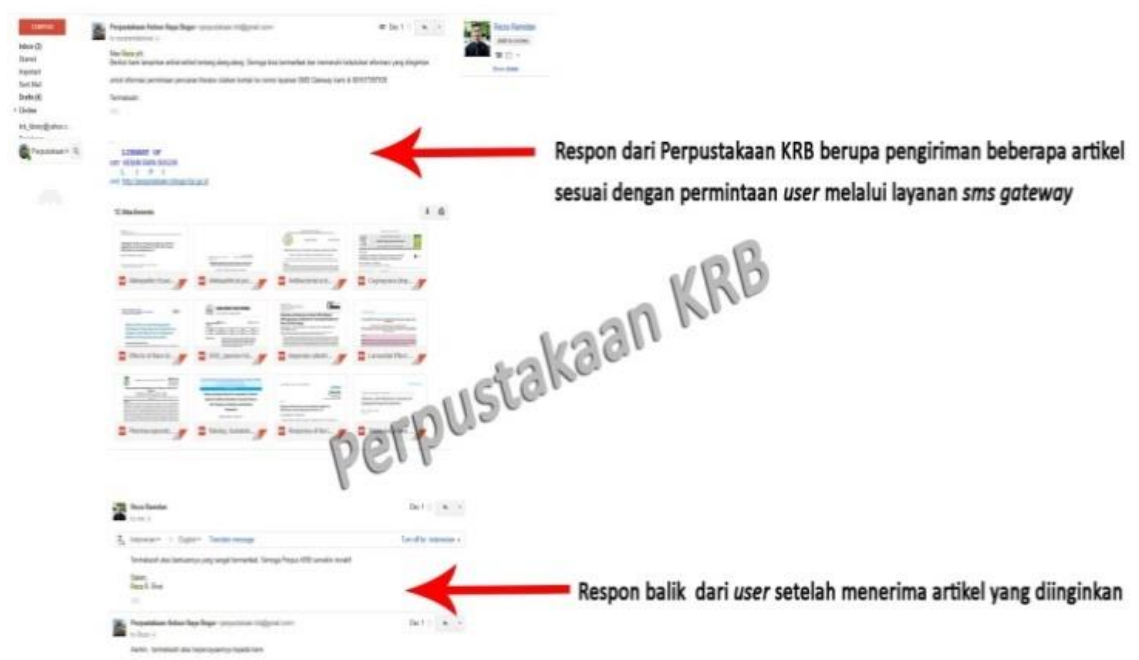

Gambar 10 Surat Elektronik yang Dikirimkan ke Peneliti Kebun Raya Bogor

\section{Pengumpulan Informasi}

Pada tahap ini, seluruh informasi yang telah dicari oleh penulis kemudian dikumpulkan untuk diseleksi. Hal ini untuk menghindari kesalahan pencarian informasi dan juga untuk memberikan hasil pencarian yang mendekati atau bahkan sesuai dengan keinginan peneliti Kebun Raya Bogor.

2. Temu-kembali Informasi

Di tahap akhir ini, mengirimkan informasi kepada peneliti di Kebun Raya Bogor melalui media surat elektronik.

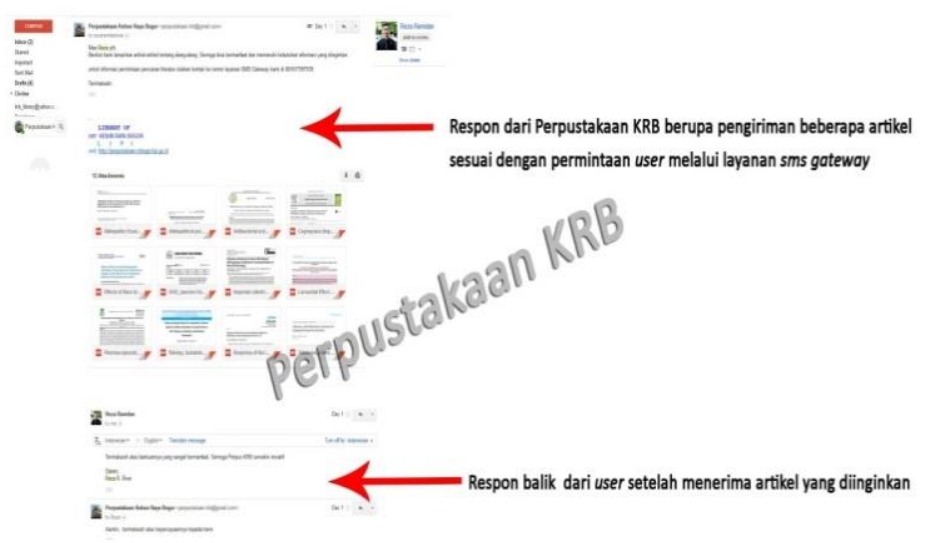

Gambar 9. Surat Elektronik (email) yang Dikirimkan ke Peneliti Kebun Raya Bogor

\section{Hasil}

\section{Hasil dari penelitian ini di tuangkan dalam bentuk analisis SWOT}

Setelah melakukan uji coba prototip pada keseluruhan Kelompok peneliti di Kebun Raya Bogor, hasilnya menggunakan analisis SWOT (Strength, Weakness, Opportunity, dan Threat). Hal ini dilakukan sebagai bahan evaluasi setelah melakukan keseluruhan tahap kerja SMS Gateway.

\section{a. Strength (kekuatan)}

Dalam proses pelaksanaan SMS Gateway, berikut adalah strength (kekuatan) yang dapat dijadikan acuan untuk kelanjutan layanan SMS ke depan.

- Penggunaan SMS Gateway berfungsi untuk membantu peneliti Kebun Raya Bogor untuk mendapatkan informasi, terutama jika berada di 
tempat-tempat yang tidak terjangkau oleh jaringan sinyal internet.

- Anggota Perpustakaan Kebun Raya Bogor dalam hal ini peneliti dapat menanyakan status pengembalian dengan mengecek via layanan autoreply. Misalnya, untuk menanyakan status peminjaman buku di perpustakaan. Anggota perpusta-kaan dapat mengirimkan sms ke nomor Perpustakaan Kebun Raya Bogor dengan mengetik STATUS[spasi](nomor barkode). Peneliti juga dapat menanyakan tentang buku yang mengandung kata/subjek tertentu.

Contoh SMS Auto Reply layanan "SMS Gateway" Perpustakaan Kebun Raya Bogor
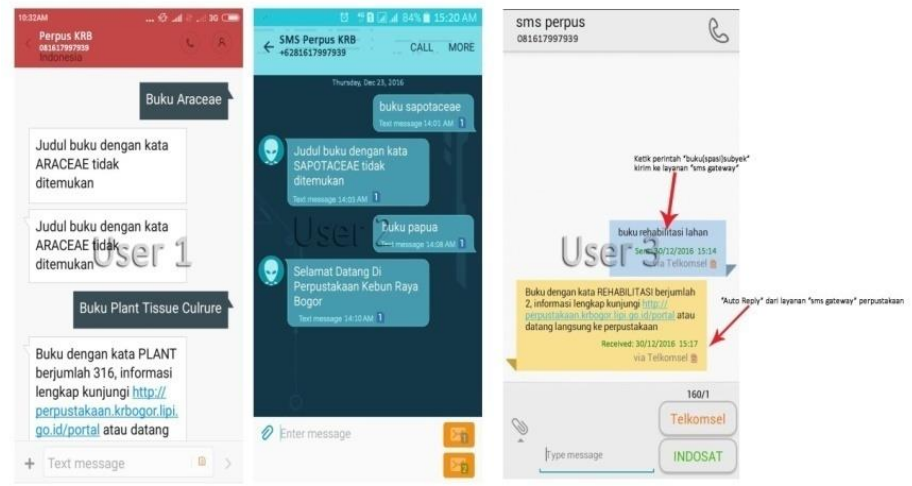

Gambar 10. Contoh SMS autoreply

- Adanya respon positif sebanyak 7 orang yang respon untuk minta dicarikan literaturnya, pada saat Perpustakaan Kebun Raya Bogor uji coba layanan SMS Gateway. Hal ini diharapkan akan memberikan dampak pada peningkatan produktivitas peneliti di Kebun Raya Bogor, baik secara kualitatif maupun kuantitatif.

\section{b. Weakness (kelemahan)}

Dalam proses pelaksanaan proyek (kelemahan) yang dapat dijadikan acuan untuk kelanjutan layanan SMS Gateway di kemudian hari.

- Koneksi internet di Kebun Raya Bogor yang sering tidak stabil, baik pada saat pencarian informasi ataupun saat membuka situs Kebun Raya Bogor/intra LIPI. Hal ini tentu saja dapat menghambat dan memperlambat pencarian informasi.

SMS Gateway, berikut adalah weakness

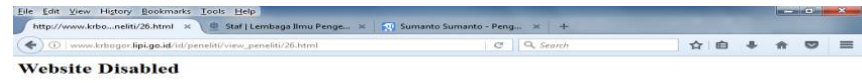

Website Disabled

Gambar 11 Situs Kebun Raya Bogor/Intra LIPI yang sering mengalami gangguan

- Perlunya perbaikan (maintenance) secara bertahap terkait dengan layanan SMS Gateway. Misalnya, pada saat pengiriman pesan singkat ke 
peneliti di Kebun Raya Bogor. pesan yang dikirim tidak bisa lebih dari 140 karakter. Artinya, jika ingin mengirimkan pesan dengan lebih dari 140 karakter, sehingga pesan harus dibagi menjadi dua atau lebih, sehingga terkesan kurang praktis.
Seharusnya, walaupun pesan yang akan dikirimkan lebih dari 140 karakter, sistem secara otomatis dapat memotong pesan sehingga informasi yang akan disampaikan terkirim secara lengkap tanpa terpotong.

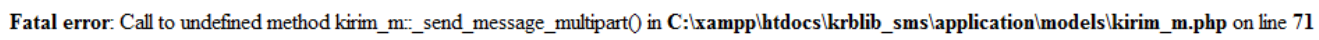

Gambar 12 Jika pesan yang akan dikirimkan melebihi kapasitas

\section{c. Opportunity (kesempatan)}

Dalam proses pelaksanaan layanan

SMS Gateway, berikut adalah opportunity (kesempatan) yang dapat dijadikan acuan untuk kelanjutan layanan tersebut di kemudian hari.

- Kolaborasi yang lebih banyak dengan peneliti di lintas Kebun Raya, baik di dalam negeri maupun luar negeri.

- Peningkatan produktivitas peneliti di Kebun Raya Bogor, baik secara kualitas maupun kuantitas.

\section{d. Threat (ancaman)}

Dalam proses pelaksanaan layanan SMS Gateway, berikut adalah threat (ancaman) yang dapat dijadikan acuan untuk kelanjutan layanan tersebut di kemudian hari.

- Untuk keberlanjutan layanan SMS Gateway, diharapkan ada tenaga ahli yang benar-benar memahami tentang proses kerja SMS Gateway. Misalnya, jika terdapat perubahan database buku dan peminjaman. Perubahan data tersebut akan berpengaruh kepada jawaban autoreply sehingga perlu adanya update informasi secara menyeluruh dan berkesinambungan.

- Apabila hasil dari pencarian dan penyebaran informasi yang dilakukan oleh staf perpustakaan pada layanan
SMS Gateway tidak berbanding lurus dengan tingkat produktivitas peneliti di Kebun Raya Bogor, maka dapat dikatakan bahwa layanan ini tidak berhasil memenuhi kebutuhan informasi peneliti di Kebun Raya Bogor.

\section{Kesimpulan dan Saran}

LayananSMS Gateway merupakan salah satu program yang dapat memberikan daya dukung terhadap penyaluran informasi, terutama di dalam lingkungan peneliti Kebun Raya Bogor, LIPI. Hal ini tentu akan berdampak pada sumbangsih perpustakaan kepada peneliti, terhadap terbitan atau karya penelitian sehingga hasilnya dapat dikembangkan atau diaplikasikan lebih lanjut. Perpustakaan Kebun Raya Bogor berharap dengan adanya layanan SMS Gateway ini, maka pemenuhan kebutuhan informasi dan tingkat produktivitas peneliti di Kebun Raya Bogor dapat meningkat seiring dengan peningkatan pelayanan perpustakaan.

\section{Daftar Pustaka:}

1. Ansor, Sokhibul \& Setiawan. 2016. Kontribusi jurnal terbitan Universitas Negeri Malang sebagai media komunikasi ilmiah dalam menumbuhkan penggunaan literatur primer bagi mahasiswa strata 1 dan 2 
Universitas Negeri Malang. Visi Pustaka. Vol. 18 no. 3. Hal. 2

2. Bielskas, A.\& Dreyer, K.M. 2012. IM and SMS reference services for libraries. Chicago: ALA Tech.source

3. Electronic Communication Committee. 2004. Short Message Service (SMS) in Fixed and Mobile Network. Diakses dari: http://test.ecodocdb.dk/docdb/download/6 2086129-e1ba/ECCREP052.PDF

4. Haidar Bagir (2016) kompas 28/4/2016.

5. K. Katankar, Veena.,\& Thakare, V.M. 2010. Short Message Service using SMS Gateway. International Journal on Computer Science and Technology. Vol. 02 no. 04.

6. Kementerian Komunikasi dan Informatika, 2015. Rencana strategis komunikasi dan informasi tahun 2015-2019.

https://web.kominfo.go.id/sites/default/file s/PM KOMINFO No 21 Tahun $2016 \mathrm{R}$ EVISI\%20RENSTRA\%20KEMKOMINFO .pdf

7. Kompas, 26 April 2016, hal. 21.

8. Stahr, B. (2009). SMS library reference service options. Library Hi Tech News. 26 (3/4): 13-15

9. Wicaksono,2017. Layanan referensi melalui SMS: Studi literatur. Media Pustakawan. Vol. 24 no. 1, hal. 4.

10. Yazdi, Mohammad. 2012. E-Learning sebagai media pembelajaran interaktif berbasis Elearning sebagai media pembelajaran interaktif berbasis teknologi informasi. Jurnal Ilmiah Foristek Vol. 2, No. 1, Maret 2012. 